"This document is the Accepted Manuscript version of a Published Work that appeared in final form in Inorganic Chemistry, copyright (C) American Chemical Society after peer review and technical editing by the publisher. To access the final edited and published work see [insert ACS Articles on Request author-directed link to Published Work, see

http://pubs.acs.org/doi/abs/10.1021/ic501483s

\title{
Dinuclear Ruthenium Complexes Containing the Hpbl Ligand: Synthesis, Characterization, Linkage Isomerism and Epoxidation Catalysis
}

Laia Francàs, ${ }^{\dagger}$ Rosa María González-Gil, ${ }^{¥}$ Daniel Moyano, ${ }^{¥}$ Jordi Benet-Buchholz, ${ }^{\dagger}$ Jordi Garcia-Antón, ${ }^{¥}$ Lluís Escriche, ${ }^{*} *$ Antoni Llobet, ${ }^{\dagger, *} *$ and Xavier Sala ${ }^{*} *$

\footnotetext{
${ }^{\dagger}$ Institute of Chemical Research of Catalonia (ICIQ), Av. Països Catalans 16, E-43007 Tarragona, Spain.

${ }^{¥}$ Departament de Química, Universitat Autònoma de Barcelona, Cerdanyola del Vallès, 08193, Barcelona, Spain.
} 
ABSTRACT: Three dinucleating $\mathrm{Ru}-\mathrm{Cl}$ complexes containing the hexadentate dinuclateing ligand $[1,1$ '-(4-methyl-1Hpyrazole-3,5-diyl)bis(1-(pyridin-2-yl)ethanol)] (Hpbl), and the meridional 2,2':6',2"-terpyridine ligand (trpy) have been prepared and isolated. These complexes include $\left\{[\operatorname{RuCl}(\operatorname{trpy})]_{2}\left(\mu-\mathrm{pbl}-\mathrm{\kappa}-\mathrm{N}^{3} \mathrm{O}\right)\right\}^{+}\left(\mathbf{1 a}^{+}\right),\left\{[\operatorname{RuCl}(\operatorname{trpy})]_{2}\left(\mu-\mathrm{Hpbl}-\kappa-\mathrm{N}^{3} \mathrm{O}\right)\right\}^{2+}$ $\left(\mathbf{1} \mathbf{b}^{2+}\right)$, and $\left\{[\mathrm{RuCl}(\mathrm{trpy})]_{2}\left(\mu-\mathrm{Hpbl}-\kappa-\mathrm{N}^{2} \mathrm{O}^{2}\right)\right\}^{2+}\left(\mathbf{1} \mathbf{c}^{2+}\right)$ and were characterized by analytic and spectroscopic techniques. In addition complexes $\mathbf{1} \mathbf{b}^{2+}$ and $\mathbf{1} \mathbf{c}^{2+}$ were characterized in the solid state by mono-crystal X-ray diffraction analysis. The coordination versatility of the Hpbl ligand allows the presence of multiple isomers that can be obtained depending on the $\mathrm{Ru}$ oxidation state and that were thoroughly characterized by electrochemical techniques namely, cyclic voltammetry and coulometry. Finally, $\mathbf{1 a}^{+}$and its recently reported mononuclear analogue, $i n-[\mathrm{RuCl}(\mathrm{Hpbl})(\operatorname{trpy})]^{+}$, have been tested as catalysts for the epoxidation of $c i s-\beta$-methylstyrene.

Keywords: Transition metal complexes, linkage isomerization, redox properties, $\mathrm{Ru}$ complexes, epoxidation catalysis. 


\section{Introduction}

Redox catalysts play a prominent role in the selective preparation of versatile intermediates for organic synthesis, as is the case for instance in the regio- and/or stereoselective transformation of double bonds into epoxides. ${ }^{1}$ The epoxides are extremely useful molecules for both the chemical industry (particularly in polymer manufacture) ${ }^{2}$ and the synthesis of fine chemicals, such as pharmaceuticals, food additives, or flavor and fragrances. ${ }^{3}$ On the other hand, water oxidation redox catalysis is one of the major topics that need to be dominated in order to come up with new energy conversion schemes that allow the transition from fossil to solar fuels. ${ }^{4}$

Mono- and dinuclear $\mathrm{Ru}$ complexes based on $\mathrm{Ru}^{\mathrm{II}}-\mathrm{OH}_{2} / \mathrm{Ru}^{\mathrm{IV}}=\mathrm{O}$ motifs, achievable via proton coupled electron transfer (PCET) processes, ${ }^{5}$ have been thoroughly studied as redox catalysts. A number of oxidative transformations including the ones mentioned above have been described. We have recently contributed to this chemistry ${ }^{6}$ focusing our attention at the influence of metal cooperation over catalysis. ${ }^{7}$ For this purpose, several dinucleating ligands (Chart 1) have been used as bridges between two Ru metal centers and the catalytic properties of the resulting complexes have been studied for the reactions of water oxidation and alkene epoxidation ${ }^{8}$

A key issue for this type of chemistry is the need to cycle among different oxidation states, such as for instance Ru(II) and $\mathrm{Ru}(\mathrm{V})$, while keeping a stable coordination environment. ${ }^{9}$ In order to come up with ligands that can stabilize low and high oxidation states we recently reported a new dinucleating bridging ligand with N/O ambidentate motifs (Hpbl, Chart 1) and its mononuclear $\mathrm{Ru}$ complexes. We have shown that when oxidation state III is reached it undergoes $\mathrm{N}->\mathrm{O}$ linkage isomerization drastically reducing redox potentials of high oxidation states. ${ }^{10}$

Here on, we report the coordination chemistry and linkage isomerization processes of dinuclear Ru-Hpbl complexes of general formula $\left\{[\operatorname{RuCl}(\operatorname{trpy})]_{2}(\mu-\mathrm{pbl})\right\}^{\mathrm{n}+}$, together with their catalytic properties with regard to the epoxidation of cis- $\beta$ methylstyrene. In addition the epoxidation capacity of their mononuclear Ru-Hpbl counterparts are also reported and compared to related complexes previously reported in the literature (Chart 1).

Chart 1. Drawing of the ligands used in this work (right) and dinucleating bridging ligands previously employed to induce metal cooperation (left).<smiles>c1ccc(-c2cc(-c3ccccn3)[nH]n2)nc1</smiles>

Hbpp

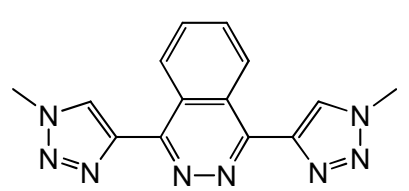<smiles>Cc1c([C@](C)(O)c2ccccn2)n[nH]c1[C@](C)(O)c1ccccn1</smiles>

$\mathrm{Hpbl}$

phtztrz

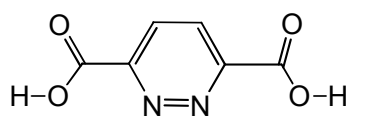

$\mathrm{H}_{2} \mathrm{pdz}-\mathrm{dc}$

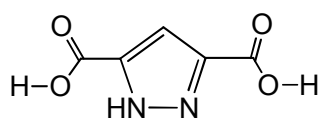

$\mathrm{H}_{3}$ pyr-dc

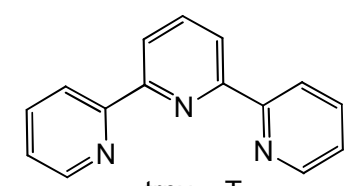

$\operatorname{trpy}=\mathrm{T}$ 


\section{Experimental Section.}

Materials. All reagents used in the present work were obtained from Sigma-Aldrich Chemical Co. and were used without further purification. Reagent grade organic solvents were obtained from SDS. $\mathrm{RuCl}_{3} \cdot 3 \mathrm{H}_{2} \mathrm{O}$ was supplied by Alfa Aesar and was used as received.

Instrumentation and Measurements. UV-Vis spectroscopy was performed by a HP8453 spectrometer using $1 \mathrm{~cm}$ quartz cells. NMR spectroscopy was performed on a Bruker DPX $250 \mathrm{MHz}$, DPX $360 \mathrm{MHz}$ or a DPX $400 \mathrm{MHz}$ spectrometer. Gas Chromatography (GC) was performed in an Agilent 6890N with a mass selective detector with ionization by electronic impact or in an Agilent 6890 GC with a flame ionization detector (FID) detector, using a HP5 column. Electrospray ionization mass spectrometry (ESI-MS) experiments were carried out on a micrOTOF-Q system from Bruker Daltonics at the Servei d'Anàlisi Química of the Universitat Autònoma de Barcelona (SAQ-UAB).

Cyclic voltammetry (CV) experiments were performed on PAR283 potentiostat, IJ-Cambria HI-660 potentiostat or BioLogic potensiostat/galvanostat and EC-Lab software using a three-electrode cell. A glassy carbon electrode (2 mm diameter) was used as working electrode, platinum wire as auxiliary electrode and SSCE as a reference electrode. Working electrodes were polished with 0.05 micron Alumina paste washed with distillated water and acetone before each measurement. $E_{1 / 2}$ values reported in this work were estimated from $\mathrm{CV}$ experiments as the average of the oxidative and reductive peak potentials $\left(E_{\mathrm{p}, \mathrm{a}}\right.$ $\left.+E_{\mathrm{p}, \mathrm{c}}\right) / 2$. All the electrochemical measurements are performed in $\mathrm{MeOH}$ with $0.1 \mathrm{M} n-\mathrm{Bu}_{4} \mathrm{~N}^{+} \mathrm{PF}_{6}^{-}$(TBAH) as supporting electrolyte.

Epoxidation catalytic experiments were performed as follows. A solution of $1.25 \cdot 10^{-3} \mathrm{mmol}$ of dinuclear catalyst (or $2.50 \cdot 10^{-}$ ${ }^{3} \mathrm{mmol}$ of mononuclear), $1.60 \mathrm{~g}(5.0 \mathrm{mmol})$ of (diacetoxyiodo)benzene ( $\left.\mathrm{PhI}(\mathrm{OAc})_{2}\right), 1 \mathrm{mmol}$ of biphenyl and $90 \mu \mathrm{L}(5.0$ $\mathrm{mmol}$ ) of water were dissolved in $1 \mathrm{~mL}$ of 1,2-dichloroethane (DCE) and allowed to stir for 2 hours. Then 2.5 mmols of substrate were added reaching a final volume of approx. $1.4 \mathrm{~mL}$. Aliquots were taken every 5, 10, 15, 20, 25, 30 min or until the reaction was completed. Each aliquot was filtered through a Pasteur pipette filled with Celite, and rinsed with diethyl ether. The filtrate was analyzed by GC and GC-MS.

Preparations. The starting complex $\left[\mathrm{RuCl}_{3}(\operatorname{trpy})\right]^{11}$ and the Hpbl ligand [1,1'-(4-methyl-1H-pyrazole-3,5-diyl)bis(1(pyridin-2-yl)ethanol) $]^{10}$ were prepared as is described in the literature. All synthetic manipulations were routinely performed under nitrogen atmosphere using Schlenck tubes and vacuum line techniques.

$\left\{[\mathbf{R u C l}(\operatorname{trpy})]_{\mathbf{2}}\left(\boldsymbol{\mu}-\mathbf{p b l}-\mathbf{k}-\mathbf{N}^{3} \mathbf{O}\right)\right\}\left(\mathbf{P F}_{\mathbf{6}}\right), \mathbf{1} \mathbf{\mathbf { a }}\left(\mathbf{P F}_{\mathbf{6}}\right)$. A sample of $200 \mathrm{mg}(0.454 \mathrm{mmol})$ of $\left[\mathrm{RuCl}_{3}(\operatorname{trpy})\right]$ and $61 \mathrm{mg}(1.439 \mathrm{mmol})$ of $\mathrm{LiCl}$ were dissolved in $20 \mathrm{~mL}$ of dry $\mathrm{MeOH}$ containing $250 \mu \mathrm{L}(1.816 \mathrm{mmol})$ of $\mathrm{NEt}_{3}$. The mixture was stirred at room temperature (RT) for $20 \mathrm{~min}$, and then $74 \mathrm{mg}(0.228 \mathrm{mmol})$ of $\mathrm{Hpbl}$ in $2.4 \mathrm{~mL}$ of a $0.29 \mathrm{M} \mathrm{MeONa}$ solution $(0.685 \mathrm{mmol})$ were added. The mixture was refluxed under stirring for $24 \mathrm{~h}$. Alternatively the reaction can also be performed in a microwave reactor by carrying out five 10 minutes heating cycles $\left(75^{\circ} \mathrm{C} / 300 \mathrm{~W}\right)$ with 5 minutes of equilibration time between them. The mixture was filtered and $2 \mathrm{~mL}$ of a saturated $\mathrm{NH}_{4} \mathrm{PF}_{6}$ aqueous solution and $5 \mathrm{~mL}$ of water were added to the filtrate. Then, the volume was reduced on a rotary evaporator until a precipitate appeared which was filtered off and dried. The obtained solid was partially dissolved in hot $\mathrm{CH}_{2} \mathrm{Cl}_{2}$, and the solution was cooled down. The remaining solid was filtered off, washed with water and diethyl ether and vacuum dried. Yield: $75 \mathrm{mg} \mathrm{(27 \% )}$ for the reflux reaction; $100 \mathrm{mg}$ (36\%) for the microwave reaction. ESI-HRMS (MeOH): $m / z=1205.0500\left([\mathrm{M}]^{+}\right)$. CV $(\mathrm{MeOH} / \mathrm{TBAH}) E_{1 / 2}=0.07 \mathrm{~V} ; E_{1 / 2}=0.77 \mathrm{~V}, \mathrm{OCP}$ : $0.1 \mathrm{~V}$. Elemental analysis calcd. (\%) for $\left(\mathrm{C}_{48} \mathrm{H}_{40} \mathrm{Cl}_{2} \mathrm{~F}_{6} \mathrm{~N}_{10} \mathrm{O}_{2} \mathrm{PRu}_{2}\right)$ : C, 47.77; H, 3.34; N, 11.61; found: C, 47.52; H, 3.45; N, 
11.37. UV-vis $(\mathrm{MeOH})\left[\lambda_{\max }, \mathrm{nm}\left(\varepsilon, \mathrm{M}^{-1} \mathrm{~cm}^{-1}\right)\right]: 276$ (26822), 283 (25083), 320 (28868), 379 (8637), 516 (5148), 585 (5956).

$\left\{[\mathbf{R u C l}(\operatorname{trpy})]_{\mathbf{2}}\left(\boldsymbol{\mu} \text {-pbl-k-N} \mathbf{N}^{3} \mathbf{O}\right)\right\}^{+}, \mathbf{1 a H}^{+}$. This complex was obtained in situ by adding ascorbic acid to a MeOD solution of 1a $^{+} .{ }^{1} \mathrm{H}$ NMR $\left(500 \mathrm{MHz}, \mathrm{MeOD}+\right.$ ascorbic acid) $\delta=10.01\left(\mathrm{~d}, 1 \mathrm{H}_{1},{ }^{3} \mathrm{~J}_{1-2}=5.62 \mathrm{~Hz}\right), 8.6-8.4\left(\mathrm{~m}, 8 \mathrm{H}_{\text {trpy }}\right), 8.26\left(\mathrm{~d}, 1 \mathrm{H}_{\text {trpy }}\right), 8.165$ $\left(\mathrm{t}, 1 \mathrm{H}_{\text {trpy }}\right), 8.076\left(\mathrm{t}, 2 \mathrm{H}_{\text {trpy }}\right), 8.000-7.875\left(\mathrm{~m}, 7 \mathrm{H}_{\text {trpy }, 2,8}\right), 7.80(\mathrm{t}, 1 \mathrm{H}), 7.74\left(\mathrm{~d}, 1 \mathrm{H}_{4},{ }^{3} \mathrm{~J}_{4-3}=5.50 \mathrm{~Hz}\right), 7.66\left(\mathrm{~d}, 1 \mathrm{H}_{\text {trpy }}\right), 7.56(\mathrm{t}$, $\left.1 \mathrm{H}_{\text {trpy }}\right), 7.50\left(\mathrm{ddd}, 1 \mathrm{H}_{9},{ }^{3} \mathrm{~J}_{9-8}=8.50 \mathrm{~Hz},{ }^{4} \mathrm{~J}_{9-10}=7.30 \mathrm{~Hz},{ }^{5} \mathrm{~J}_{9-11}=1.44 \mathrm{~Hz}\right), 7.40\left(\mathrm{t}, 1 \mathrm{H}_{\text {trpy }}\right), 7.27\left(\mathrm{ddd}, 1 \mathrm{H}_{3},{ }^{3} \mathrm{~J}_{3-2}=7.70 \mathrm{~Hz},{ }^{4} \mathrm{~J}_{3-4}=5.50\right.$ $\left.\mathrm{Hz},{ }^{5} \mathrm{~J}_{3-1}=1.10 \mathrm{~Hz}\right), 7.25\left(\mathrm{~d}, 1 \mathrm{H}_{11},{ }^{3} \mathrm{~J}_{11-10}=5.80 \mathrm{~Hz}\right), 6.61\left(\mathrm{ddd}, 1 \mathrm{H}_{10},{ }^{3} \mathrm{~J}_{10-9}=7.30 \mathrm{~Hz},{ }^{4} \mathrm{~J}_{10-11}=5.80 \mathrm{~Hz}, \mathrm{~J}_{10-8}=1.50 \mathrm{~Hz}\right), 2.14(\mathrm{~s}$, $\left.3 \mathrm{H}_{6}\right), 1.67\left(\mathrm{~s}, 3 \mathrm{H}_{5}\right), 1.44\left(\mathrm{~s}, 3 \mathrm{H}_{7}\right)$. UV-vis $(\mathrm{MeOH})\left[\lambda_{\max }, \mathrm{nm}\left(\varepsilon, \mathrm{M}^{-1} \mathrm{~cm}^{-1}\right)\right]: 280$ (26692), 282 (27401), $320(33910), 379$ (9798), 489 (6321), 527 (6166).

$\left\{[\mathbf{R u C l}(\operatorname{trpy})]_{2}\left(\boldsymbol{\mu}-\mathbf{H p b l}-\kappa-\mathbf{N}^{3} \mathbf{O}\right)\right\}\left(\mathbf{P F}_{\mathbf{6}}\right)_{2}, \mathbf{1 b}\left(\mathbf{P F}_{\mathbf{6}}\right)_{2}$. A sample of $50 \mathrm{mg}(0.04 \mathrm{mmol})$ of $\mathbf{1 a}\left(\mathbf{P F}_{\mathbf{6}}\right)$ was dissolved in $50 \mathrm{~mL}$ of $\mathrm{MeOH}$. The mixture was left stirring at room temperature for 1 week. Then, saturated aqueous $\mathrm{NH}_{4} \mathrm{PF}_{6}(0.2 \mathrm{~mL})$ and water $(0.5 \mathrm{~mL})$ were added to the solution and the volume was reduced on a rotary evaporator. The solution was cooled at $-33{ }^{\circ} \mathrm{C}$ overnight. A brown precipitate appeared, which was filtered off and washed with cold methanol and dried with diethyl ether. Yield: $35 \mathrm{mg}(65 \%)$. ESI-MS $(\mathrm{MeOH}): m / z=531.5\left(\left[\mathrm{M}-2 \mathrm{PF}_{6}\right]^{2+}\right)$. CV $(\mathrm{MeOH} / \mathrm{TBAH}) E_{1 / 2}=0.3 \mathrm{~V} ; E_{1 / 2}=0.77 \mathrm{~V}, \mathrm{OCP}$ : $0.465 \mathrm{~V}$. Elemental analysis calcd. (\%) for $\left(\mathrm{C}_{48} \mathrm{H}_{41} \mathrm{Cl}_{2} \mathrm{~F}_{12} \mathrm{~N}_{10} \mathrm{O}_{2} \mathrm{P}_{2} \mathrm{Ru}_{2}\right)$ : C, 42.61; H, 3.05; N, 10.35; found: C, 42.47; H, 3.04; $\mathrm{N}, 10.23$. UV-vis $(\mathrm{MeOH})\left[\lambda_{\max }, \mathrm{nm}\left(\varepsilon, \mathrm{M}^{-1} \mathrm{~cm}^{-1}\right)\right]: 275$ (34171), 281 (32372), 318 (30894), 377 (7216), 475 (5088), 513 (4062).

$\left\{[\mathbf{R u C l}(\text { trpy })]_{2}\left(\boldsymbol{\mu}-\mathrm{Hpbl}-\kappa-\mathbf{N}^{2} \mathbf{O}^{2}\right)\right\}\left(\mathbf{P F}_{6}\right)_{2} \cdot \mathbf{M e O H}, \mathbf{1 c}\left(\mathbf{P F}_{6}\right)_{2} \cdot \mathbf{M e O H}$. A sample of $50 \mathrm{mg}(0.040 \mathrm{mmol})$ of $\mathbf{1 a}\left(\mathbf{P F}_{6}\right)$ and 24.02 $\mathrm{mg}(0.044 \mathrm{mmol})$ of $\mathrm{Ce}\left(\mathrm{NO}_{3}\right)_{6}\left(\mathrm{NH}_{4}\right)_{2}$ were dissolved in $50 \mathrm{~mL}$ of methanol. The mixture was stirred at room temperature for 4 days under nitrogen atmosphere. Then, the mixture was filtered and the solvent was evaporated and replaced by $\mathrm{CH}_{2} \mathrm{Cl}_{2}$. The insoluble portion was filtered off and the filtered solution was washed with $20 \mathrm{~mL}$ of water plus $20 \mathrm{~mL}$ of a saturated $\mathrm{NaCl}$ solution. The organic fraction was then dried with anhydrous $\mathrm{Na}_{2} \mathrm{SO}_{4}$, filtered and evaporated to dryness. The residue was re-dissolved in methanol and $0.2 \mathrm{~mL}$ of a saturated aqueous solution of $\mathrm{NH}_{4} \mathrm{PF}_{6}$ were added together with $0.5 \mathrm{~mL}$ of water. The volume was then reduced on a rotary evaporator until a precipitate appeared and the remaining solution cooled at $-33^{\circ} \mathrm{C}$ overnight. The brown solid formed was filtered off, washed with cold methanol and dried with diethyl ether and under vacuum. Yield: $11 \mathrm{mg}(20 \%)$. CV (MeOH/TBAH) $E_{1 / 2}=0.30 \mathrm{~V}$, OCP: $0.468 \mathrm{~V}$. Elemental analysis calcd. (\%) for $\left(\mathrm{C}_{49} \mathrm{H}_{44} \mathrm{Cl}_{2} \mathrm{~F}_{12} \mathrm{~N}_{10} \mathrm{O}_{3} \mathrm{P}_{2} \mathrm{Ru}_{2}\right)$ : C, 42.53; H, 3.20; N, 10.12; found: C, 42.47; H, 3.04; N, 10.23. UV-vis (MeOH) [ $\lambda_{\max }, \mathrm{nm}^{(}\left(\varepsilon, \mathrm{M}^{-}\right.$

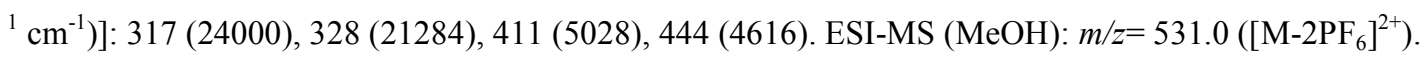

X-ray Crystal Structure Determinations. Crystals of both complexes $\mathbf{1 b}\left(\mathbf{P F} \mathbf{F}_{\mathbf{6}}\right)_{\mathbf{2}}$ and $\mathbf{1} \mathbf{c}\left(\mathbf{P F}_{\mathbf{6}}\right)_{\mathbf{2}}$ were obtained by slow diffusion of diethyl ether into an acetone solution containing complex $\mathbf{1} \mathbf{a}\left(\mathbf{P F}_{\mathbf{6}}\right)$ at room temperature and in the presence of atmospheric oxygen. The measured crystals were prepared under inert conditions immersed in perfluoropolyether as protecting oil for manipulation.

Data collection: Crystal structure determinations for $\mathbf{1 b}\left(\mathbf{P F}_{\mathbf{6}}\right)_{\mathbf{2}}$ and $\mathbf{1} \mathbf{c}\left(\mathbf{P F}_{\mathbf{6}}\right)_{\mathbf{2}}$ were carried out using a Bruker-Nonius diffractometer equipped with an APEX II 4K CCD area detector, a FR591 rotating anode with MoKa radiation, Montel mirrors as monochromator, a Kappa 4-axis goniometer and an Oxford Cryosystems low temperature device Cryostream 700 plus $(\mathrm{T}=-$ $\left.173{ }^{\circ} \mathrm{C}\right)$. Full-sphere data collection was used with $\omega$ and $\varphi$ scans. Programs used: Data collection with APEX-2, ${ }^{12}$ data reduction with Bruker Saint ${ }^{13}$ and absorption correction with SADABS $^{14}$ 
Structure Solution and Refinement: Crystal structure solution was achieved using direct methods as implemented in SHELXTL ${ }^{15}$ and visualized using the program XP. Missing atoms were subsequently located from difference Fourier synthesis and added to the atom list. Least-squares refinement on F2 using all measured intensities was carried out using the program SHELXTL. All non-hydrogen atoms were refined including anisotropic displacement parameters.

Comments to the structures: Compound $\mathbf{1 b}\left(\mathbf{P F}_{\mathbf{6}}\right)_{2}$ crystallizes with one molecule of the metal complex, two $\mathrm{PF}_{6}$ anions, two acetone molecules and a half molecule of water in the asymmetric unit. One of the acetone molecules is disordered in two positions with a ratio of 53:47. The water molecule is also disordered (50:50) and shared with the neighboring unit cell. Compound $\mathbf{1} \mathbf{c}\left(\mathbf{P F}_{\mathbf{6}}\right)_{2}$ crystallizes with one molecule of the metal complex, two $\mathrm{PF}_{6}$ anions and two and half molecules of water in the asymmetric unit. One of the $\mathrm{PF}_{6}$ anions is disordered in two positions (ratio 60:40). The water molecules are highly disordered with an occupancy of 1.00:0.75:0.50:0.125:0.125. As a consequence of this, the hydrogen atoms of the water molecules could not be precisely localized (B alert in the CheckCIF report).

\section{Results and Discussion}

1. Synthesis and Structure. The dinuclear complex $\mathbf{1} \mathbf{a}\left(\mathbf{P F}_{\mathbf{6}}\right)$ is prepared using $\left[\mathrm{RuCl}_{3}(\operatorname{trpy})\right]$ as metal precursor in combination with the $\mathrm{Hpbl}$ ligand (Scheme 1) under inert conditions in a 2:1 $\mathrm{MeONa}:\left[\mathrm{RuCl}_{3}\right.$ (trpy)]:Hpbl molar ratio with excess of $\mathrm{MeONa}$ as a base. Either reflux or microwave heating in $\mathrm{MeOH}$ can be used giving similar results with moderate yields $(27$ $\%$ for conventional reflux and $36 \%$ for microwave). Complex $\mathbf{1 a}\left(\mathbf{P F}_{\mathbf{6}}\right)$ is then washed with hot $\mathrm{CH}_{2} \mathrm{Cl}_{2}$.

Scheme 1. Synthetic strategy for the preparation of the complexes described in this work. The terpyridine ligand is represented with three $\mathrm{N}$ atoms linked by arcs. Color code for $\mathrm{Ru}$ : orange for oxidation state II and fuchsia for oxidation state III. This color code is used from now on in all the schemes.

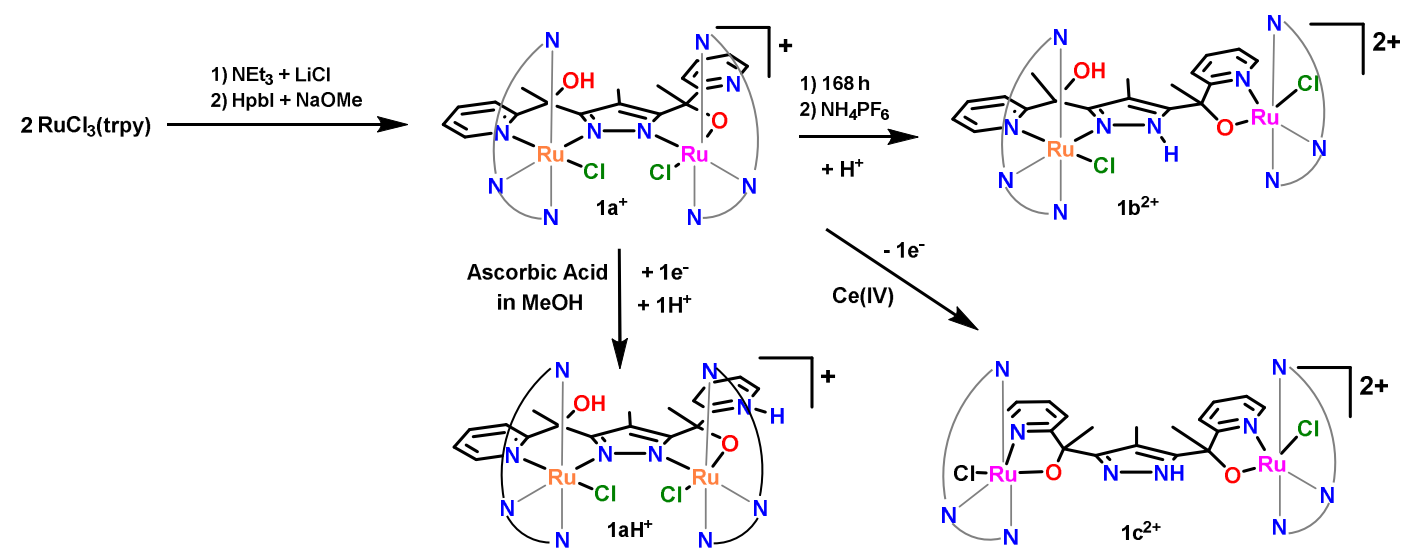

There are a number of potential $\mathrm{Ru}-\mathrm{Cl}$ dinuclear complexes that can be obtained given the chelating, dinucleating hexadentate nature of the Hpbl ligand and assuming that the trpy ligands remain always bonded to the Ru metal center. Scheme 2 , presents a drawing of all these potential isomers at oxidation state II, classified as a function of the N/O pbl ${ }^{-}$chelating atoms, where $\mathrm{pbl}^{-}$ligand can have different degrees of protonation. 
Scheme 2. Structure of all the possible isomeric species for dinuclear $\mathrm{Ru}^{\mathrm{II}}-\mathrm{Cl}$ complexes bearing the $\mathrm{Hpbl}$ and trpy ligands.
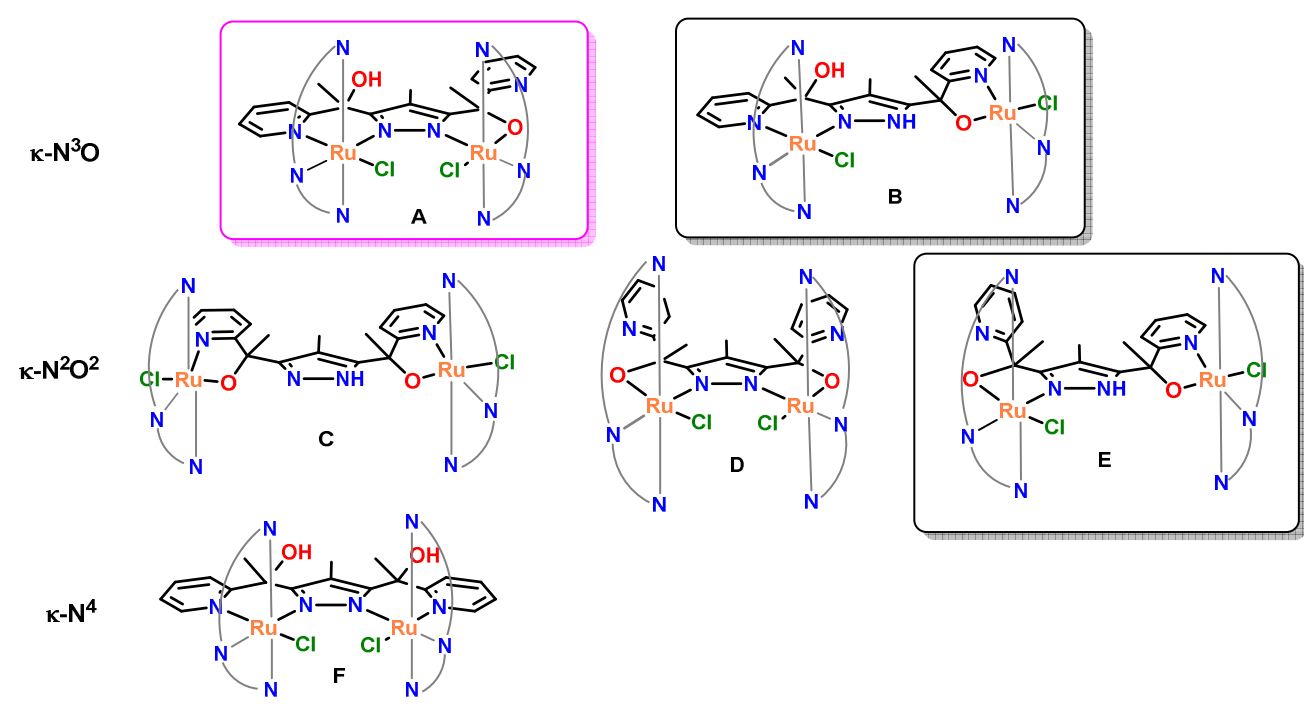

From a geometrical perspective it is interesting to realize that species $\mathrm{C}, \mathrm{D}$ and $\mathrm{F}$ (Scheme 2) contain a $C_{2}$ rotation axis that bisects the pyrazolyl moiety of the $\mathrm{pbl}^{-}$ligand, whereas species A, B and $\mathrm{E}$ have no symmetry elements except for the identity, " $E$ ". This is important since analytic techniques such as NMR allow us to discern between symmetric and non-symmetric species. The ${ }^{1} \mathrm{H}$ NMR spectrum of the dinuclear complex $\mathbf{1 a}^{+}$presents broad resonances (see Figure $\mathrm{S} 1$ in the Supporting Information) suggesting the paramagnetic nature of the $\mathrm{Ru}(\mathrm{II})-\mathrm{Ru}(\mathrm{III})$ complex. This is further confirmed by the open circuit potential situated above the first oxidation wave (see below). The addition of a reducing agent such as ascorbic acid to a NMR tube containing this paramagnetic complex generates the diamagnetic $1 \mathbf{a H}^{+}$complex, whose ${ }^{1} \mathrm{H}$ NMR spectrum is presented in Figure 1 and Figure S2 in the supporting information. Based on the number of resonances and their integration, this NMR is consistent with a non-symmetric complex containing two terpyridines and one Hpbl ligand. Accordingly, the symmetric species (C, D and F, Scheme 2) are discarded. 


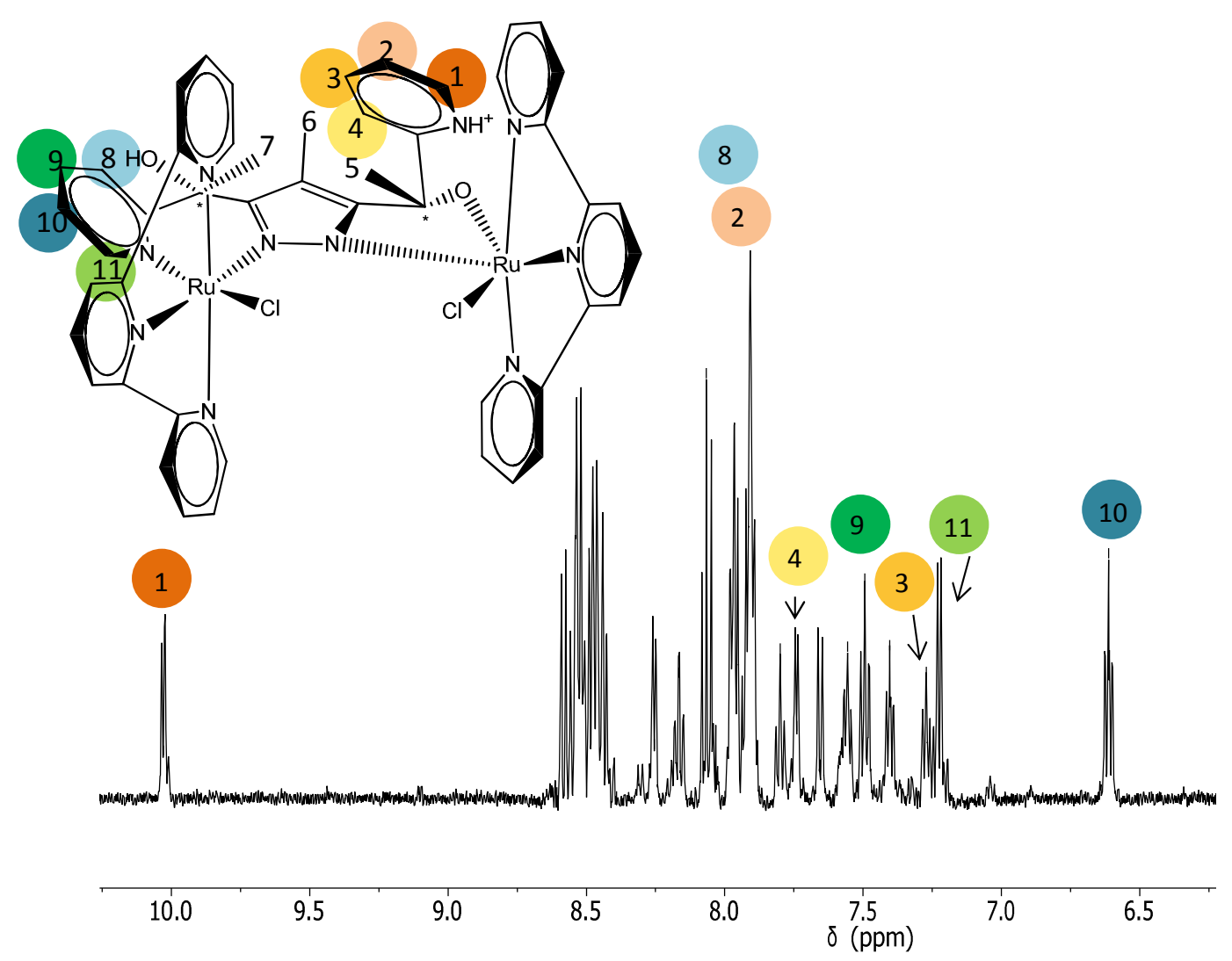

Figure 1. ${ }^{1} \mathrm{H}$ NMR spectra for the complex $\mathbf{1} \mathbf{a H}^{+}$in MeOD generated from the addition of ascorbic acid to $\mathbf{1 \mathbf { a } ^ { + }}$ and numbering scheme.

For Ru-Hbpp complexes we have a substantial number of both mononuclear and dinuclear complexes ${ }^{7 \mathrm{a}, 9 \mathrm{a}, \mathrm{b}, 10,16}$ that have been thoroughly characterized by ${ }^{1} \mathrm{H}$ NMR spectroscopy. For these complexes the trans-influence of the Ru-Cl group induces the presence of a pseudo-triplet at 6-7 ppm due to the pyridyl group of the Hbpp ligand. The fact that in the present case we only find one triplet in this region suggests that one pyridyl of $\mathrm{pbl}^{-}$is coordinated whereas the other one is not. The noncoordinated $\mathrm{Hpbl}$ pyridyl group at low $\mathrm{pH}$ is protonated and this produces the appearance of a doublet above $10.0 \mathrm{ppm}$ due to the $\mathrm{CH}$ alpha to the pyridyl $\mathrm{N}$-atom. Furthermore, this is also in agreement with the experimental potentials found in the $\mathrm{CV}$ which indicate a $\mathrm{N}_{5}$ type of coordination environment for one of the Ru metal centers, and a $\mathrm{ON}_{4}(\mathrm{Pz})$ for the second one, as will be detailed later on. This discards species B and E as potential candidates. Finally and in addition to the previous arguments, electrochemistry allows discriminating between species "A" and "E". A wave at $0.78 \mathrm{~V}$ associated with a Ru first coordination sphere environment of $5 \mathrm{~N}$-pyridyl and $\mathrm{Cl}$ appears at the cyclic voltammetry which allows to assign this complex to species "A" since species "E" would have a much lower redox potential given the alkoxo coordination of its Ru centers (vide infra) (Table 1). ${ }^{10}$ Furthermore the complex has been characterized by UV-Vis and MS techniques (See figures S7, S8 and S10 in the supporting information) 
Table 1. Electrochemical Data for Mononuclear ${ }^{10}$ and Dinuclear Hpbl Complexes.

\begin{tabular}{|c|c|c|}
\hline Entry & Complex ${ }^{\mathrm{a}}$ & $\begin{array}{c}E_{1 / 2} v s . \mathrm{SSCE} \text { in V } \\
\mathrm{Ru}(\mathrm{III} / \mathrm{II})\end{array}$ \\
\hline $1^{\mathrm{a}}$ & {$\left[\mathbf{R u}-\mathrm{N}_{5}-\mathrm{H}_{2} \mathrm{O}\right]^{2+10}$} & 0.72 \\
\hline $2^{\mathrm{a}}$ & {$\left[\mathbf{R u}-\mathrm{ON}_{4}(\mathrm{Pz})-\mathrm{H}_{2} \mathrm{O}\right]^{2+10}$} & 0.24 \\
\hline $3^{\mathrm{a}}$ & {$\left[\mathbf{R u}-\mathrm{ON}_{4}(\mathrm{Py})-\mathrm{H}_{2} \mathrm{O}\right]^{2+10}$} & 0.38 \\
\hline $4^{\mathrm{b}}$ & {$\left[\mathrm{Cl}-(\mathrm{Pz}) \mathrm{N}_{4} \mathrm{O}-\mathrm{Ru}--\mathrm{Ru}-\mathrm{N}_{5}-\mathrm{Cl}\right]^{+}, \mathbf{1 a}^{+}$} & 0.78 \\
\hline $5^{\mathrm{b}}$ & {$\left[\mathrm{Cl}-(\mathrm{Pz}) \mathrm{N}_{4} \mathrm{O}-\mathrm{Ru}--\mathrm{Ru}-\mathrm{N}_{5}-\mathrm{Cl}\right]^{+}, \mathbf{1 a}^{+}$} & 0.07 \\
\hline $6^{\mathrm{b}}$ & {$\left[\mathrm{Cl}-(\mathrm{Py}) \mathrm{N}_{4} \mathrm{O}-\mathrm{Ru}-\mathrm{-Ru}-\mathrm{N}_{5}-\mathrm{Cl}\right]^{2+}, \mathbf{1 b}^{2+}$} & 0.78 \\
\hline $7^{\mathrm{b}}$ & {$\left[\mathrm{Cl}-(\mathrm{Py}) \mathrm{N}_{4} \mathrm{O}-\mathrm{Ru}--\mathrm{Ru}-\mathrm{N}_{5}-\mathrm{Cl}\right]^{2+}, \mathbf{1 b}^{2+}$} & 0.3 \\
\hline $8^{\mathrm{b}}$ & {$\left[\mathrm{Cl}-(\mathrm{Py}) \mathrm{N}_{4} \mathrm{O}-\mathbf{R u}--\mathrm{Ru}-\mathrm{ON}{ }_{4}(\mathrm{Py})-\mathrm{Cl}\right]^{2+}, \mathbf{1 c}^{2+}$} & 0.3 \\
\hline $\begin{array}{l}{ }^{\mathrm{a}} \text { in } 0.1 \\
\mathrm{~b} \text { in } 0.1 \\
{ }^{\mathrm{c}} \text { in bo }\end{array}$ & $\begin{array}{l}\text { of triflic acid aqueous solution. } \\
\text { of TBAH in MeOH } \\
\text { re indicated the metal center undergoing the }\end{array}$ & \\
\hline \multicolumn{3}{|c|}{ d the complexes are labelled indicating the atoms at the first Ru coordination sphere. } \\
\hline \multicolumn{3}{|c|}{$\begin{array}{l}\mathrm{NO}(\mathrm{N}(\mathrm{Py}) \text { when coordinated by the pyridyl group or } \mathrm{N}(\mathrm{Pz}) \text { by the pyrazolyl). Finally } \\
\text { the } \mathrm{H}_{2} \mathrm{O} \text { or } \mathrm{Cl} \text { ligands are explicitly written. }\end{array}$} \\
\hline
\end{tabular}

Complex $\mathbf{1 a}^{+}$slowly isomerizes into $\mathbf{1 b}^{2+}$ in $\mathrm{MeOH}$ at room temperature (one week) substituting the initial coordinated pyrazolyl moiety from $\mathrm{pbl}^{-}$by the free pyridyl on the alkoxo side and generating a $\mathrm{Ru}^{\mathrm{III}}-\mathrm{ON}_{4}(\mathrm{Py})$ moiety (Scheme 1). An X-ray structure of this new complex is presented in Figure 2 that will be discussed below. The UV-Vis spectrum, the CV and the MS spectrum are shown in the supporting information figures S4, S8 and S11, respectively.

Addition of 1 equivalent of $\mathrm{Ce}(\mathrm{IV})$ to a methanolic solution of the mixed valence $\mathrm{Ru}^{\text {III }}-\mathrm{Ru}^{\mathrm{II}}$ complex $1 \mathbf{a}^{+}$at room temperature generates the dinuclear complex $\mathbf{1} \mathbf{c}^{2+}$ where both Ru centers are now at oxidation state III,III. The first coordination sphere of the latter is $\mathrm{Ru}^{\mathrm{III}}-\mathrm{ON}_{4}(\mathrm{Py})$, that is with alkoxo coordination, with the two pyridyls from the pbl' ligands also coordinated. In addition the $\mathrm{N}$-atoms of the pyrazolate moiety are not involved in the metal coordination as can be seen in the crystal structure in Figure 2 and also in a drawing in Scheme 1. (See figures S5, S9 and S12 in the supporting information for further characterization)
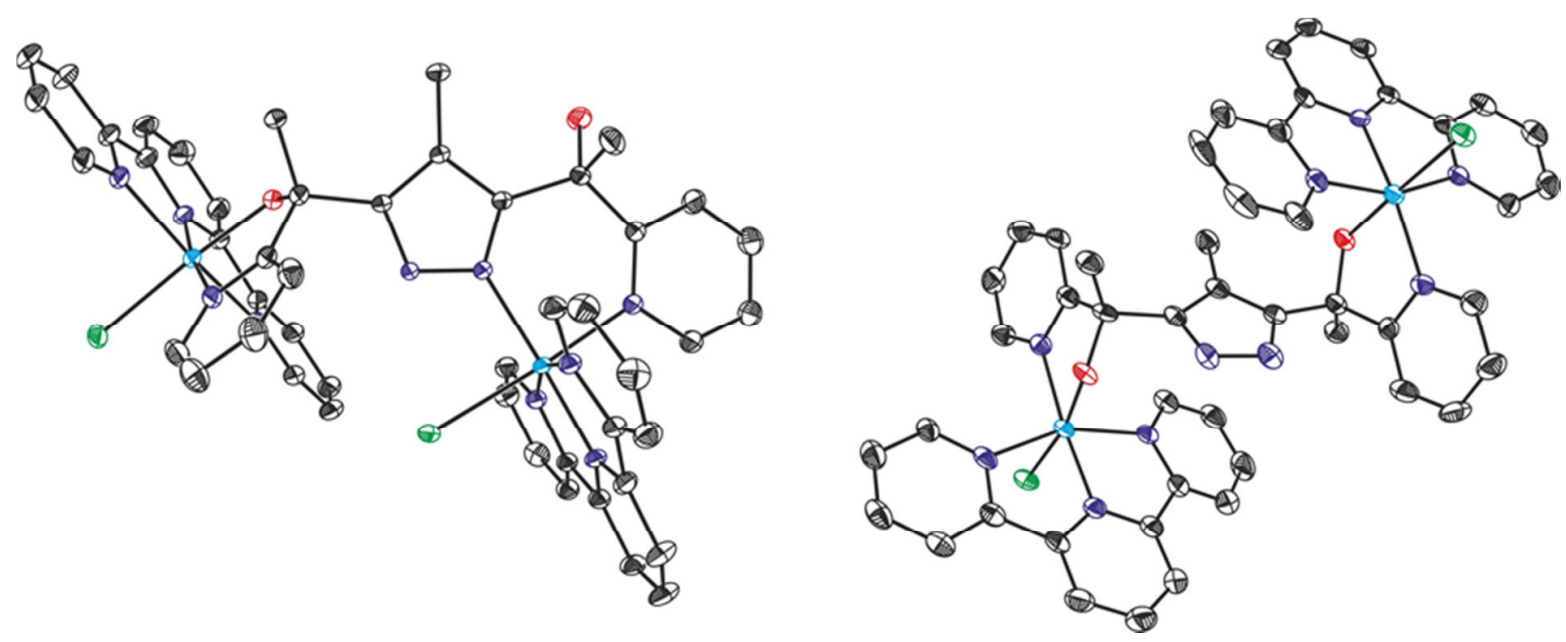

Figure 2. ORTEP plots (thermal ellipsoids at $50 \%$ probability) for the X-ray crystal structures of the cationic part of the complexes: $\mathbf{1 b}^{\mathbf{2 +}}$ (left) and $\mathbf{1} \mathbf{c}^{\mathbf{2}}$ (right). Hydrogen atoms have been omitted for clarity. Color codes: C, black; $\mathrm{Cl}$, green; $\mathrm{N}$, dark blue; $\mathrm{O}$, red; Ru, light blue. 
Table 2. Crystallographic Data for Complexes $\left[\mathbf{1 b}\left(\mathrm{PF}_{6}\right)_{2}\right] \cdot\left(\mathrm{C}_{3} \mathrm{H}_{6} \mathrm{O}\right)_{2} \cdot\left(\mathrm{H}_{2} \mathrm{O}\right)_{0.5}$ and $\left[\mathbf{1}\left(\mathrm{PF}_{6}\right)_{2}\right] \cdot\left(\mathrm{H}_{2} \mathbf{O}\right)_{2.5} \cdot$

\begin{tabular}{|c|c|c|}
\hline Compound & {$[1 \mathrm{~b}]\left(\mathrm{PF}_{6}\right)_{2} \cdot\left(\mathrm{C}_{3} \mathrm{H}_{6} \mathrm{O}\right)_{2} \cdot\left(\mathrm{H}_{2} \mathrm{O}\right)_{0.5}$} & {$[1 \mathrm{c}]\left(\mathrm{PF}_{6}\right)_{2} \cdot\left(\mathrm{H}_{2} \mathrm{O}\right)_{2.5}$} \\
\hline Formula & $\mathrm{C}_{54} \mathrm{H}_{54} \mathrm{Cl}_{2} \mathrm{~F}_{12} \mathrm{~N}_{10} \mathrm{O}_{4.5} \mathrm{P}_{2} \mathrm{Ru}_{2}$ & $\mathrm{C}_{48} \mathrm{H}_{44} \mathrm{Cl}_{2} \mathrm{~F}_{12} \mathrm{~N}_{10} \mathrm{O}_{4.5} \mathrm{P}_{2} \mathrm{Ru}_{2}$ \\
\hline Solvent detected & $1 / 2 \mathrm{H}_{2} \mathrm{O}+2$ Acetone & $2.5 \mathrm{H}_{2} \mathrm{O}$ \\
\hline Formula weight & 1478.05 & 1395.91 \\
\hline Crystal size $\left(\mathrm{mm}^{3}\right)$ & $0.50 \times 0.20 \times 0.05$ & $0.20 \times 0.10 \times 0.05$ \\
\hline Crystal color & brown & red \\
\hline Temp (K) & 100 & 100 \\
\hline Crystal system & triclinic & triclinic \\
\hline Space group & $P \overline{1}$ & $P \overline{1}$ \\
\hline $\mathrm{A}(\AA)$ & $12.5295(6)$ & $13.2322(9)$ \\
\hline $\mathrm{B}(\AA)$ & $14.6459(7)$ & $15.2695(10)$ \\
\hline $\mathrm{C}(\AA)$ & $18.2104(9)$ & $15.8750(10)$ \\
\hline$\alpha(\operatorname{deg})$ & $107.284(2)$ & $70.027(2)$ \\
\hline$\beta(\operatorname{deg})$ & $109.045(2)$ & $68.822(2)$ \\
\hline$\gamma(\operatorname{deg})$ & $96.360(2)$ & $89.430(2)$ \\
\hline $\mathrm{V}\left(\AA^{3}\right)$ & $2935.2(2)$ & 2787.4(3) \\
\hline Z & 2 & 2 \\
\hline$\rho\left(\mathrm{g} / \mathrm{cm}^{3}\right)$ & 1.672 & 1.663 \\
\hline$\mu\left(\mathrm{mm}^{-1}\right)$ & 0.754 & 0.789 \\
\hline$\theta_{\max }\left({ }^{\circ}\right)$ & 36.60 & 26.38 \\
\hline Reflec. measured & 101293 & 24599 \\
\hline Unique reflections obv. & $20024\left[\mathrm{R}_{\mathrm{int}}=0.0696\right]$ & $8054\left[\mathrm{R}_{\mathrm{int}}=0.0853\right]$ \\
\hline Absorpt. correct. & SADABS & SADABS \\
\hline Trans. $\min / \max$ & $0.871 / 1.000$ & $0.703 / 0.962$ \\
\hline Parameters & 834 & 845 \\
\hline $\mathrm{R} 1 / \mathrm{wR} 2[\mathrm{I}>2 \sigma(\mathrm{I})]$ & $0.0415 / 0.0980$ & $0.0568 / 0.1537$ \\
\hline $\mathrm{R} 1 / w \mathrm{wR}$ [all data] & $0.0758 / 0.1186$ & $0.0873 / 0.1796$ \\
\hline Goodness-of-fit $\left(\mathrm{F}^{2}\right)$ & 1.037 & 1.036 \\
\hline Peak/hole $\left(\mathrm{e} / \AA^{3}\right)$ & $1.235 /-0.977$ & $1.373 /-1.002$ \\
\hline
\end{tabular}

The solid state structure for the cationic parts of $\mathbf{1} \mathbf{b}^{2+}$ and $\mathbf{1} \mathbf{c}^{2+}$ are very similar to related low spin $\mathrm{d}^{6} \mathrm{Ru}(\mathrm{II})$ and low spin $\mathrm{d}^{5}$ $\mathrm{Ru}(\mathrm{III})$ complexes previously published in the literature showing pseudo-octahedral geometry ${ }^{6,7,8,9}$ For complex $\mathbf{1} \mathbf{b}^{2+}$ it is interesting to realize that the pyrazolyl coordinating side generates a 6 member ring metallacycle with the Ru metal center whereas the other metal center with no pyrazolyl coordination generates a 5 member ring. This can be an important factor in the isomerization driving force. ${ }^{17}$ In addition this new coordination environment produces a large separation between the two $\mathrm{Cl}$ ligands that are now situated at $6.8 \AA$. This is important from a reactivity perspective because it will preclude an intramolecular interaction between potential active sites derived from their substitution. The latter is even more strongly manifested

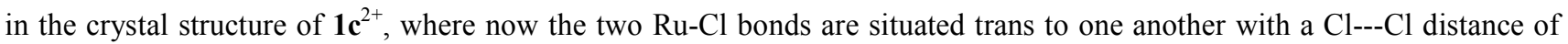
$12.7 \AA$.

\section{Redox chemistry and linkage isomerism.}

The electrochemical behavior of the dinuclear complex $\mathbf{1 a}^{+}$has also been studied by cyclic voltammetry in $\mathrm{MeOH}$ and the potential complexes generated and their generation routes are mapped in Scheme 3. 
Scheme 3. Schematic representation of the different linkage isomerization processes taking place for $\mathbf{1 a}^{+}$and its $1 \mathrm{e}^{-}$oxidized and reduced species. Here the terpyridine ligand is represented by " $T$ " and its axial coordination positions are not shown for clarity purposes.

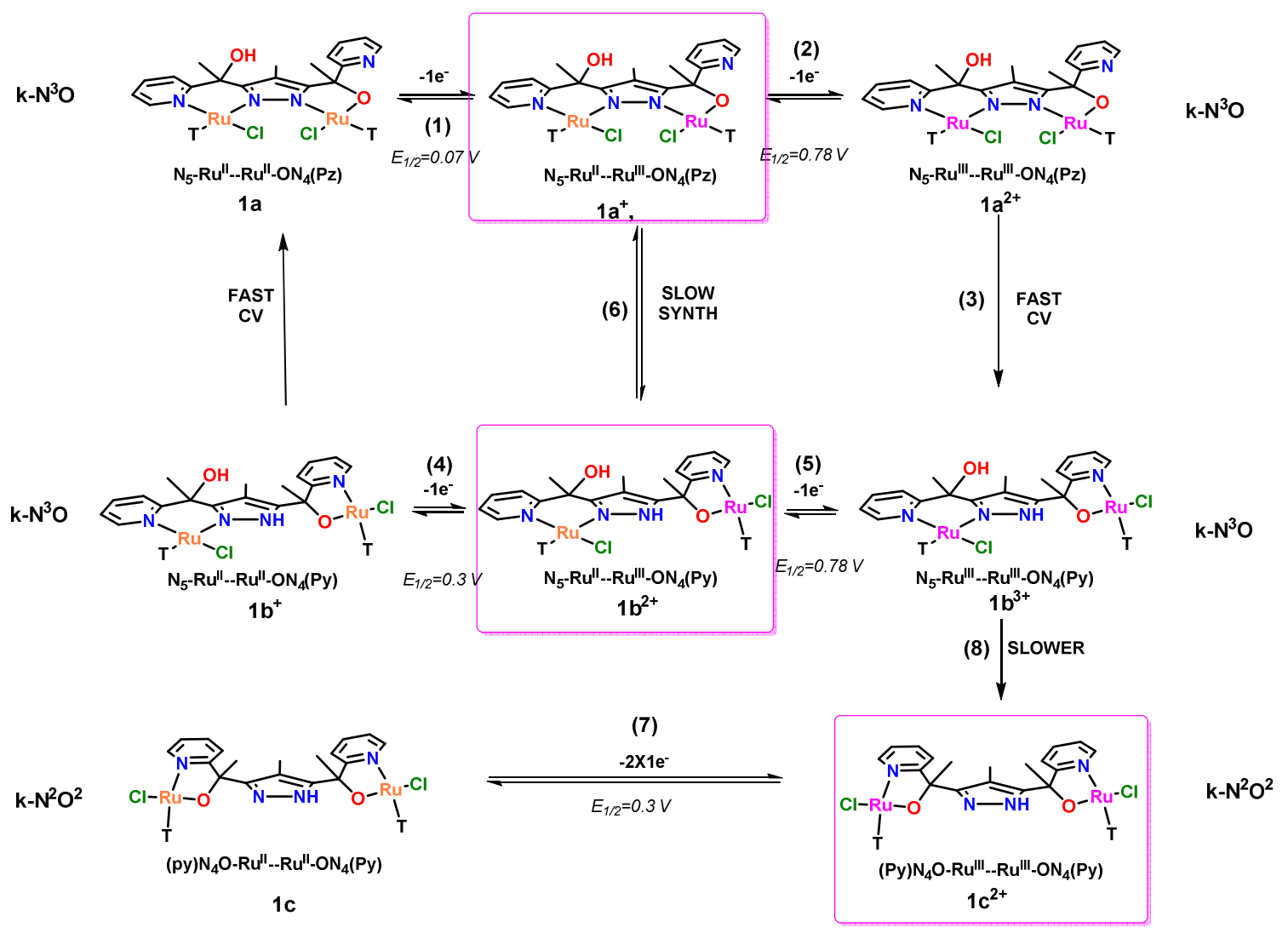

In order to facilitate the tracking of the different species generated electrochemically we are using a nomenclature that only shows the first coordination sphere. In this nomenclature the $\mathrm{Cl}$ ligands are not shown since they are always coordinated as are the trpy ligands that are displayed with three "N". The other two positions for the octahedral coordination of the Ru metal

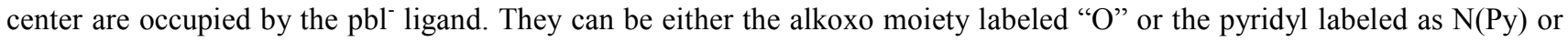
the pyrazolyl labeled as $\mathrm{N}(\mathrm{Pz})$. In the case where both pyridyl and pyrazolyl groups are coordinated, they are labeled with two "N". For instance $\mathbf{1 a}^{+}$is labeled as " $\mathrm{N}_{5}-\mathrm{Ru}^{\mathrm{II}}--\mathrm{Ru}^{\mathrm{III}}-\mathrm{ON}_{4}(\mathrm{Pz})$ " as indicated in Scheme 3. 
(a)

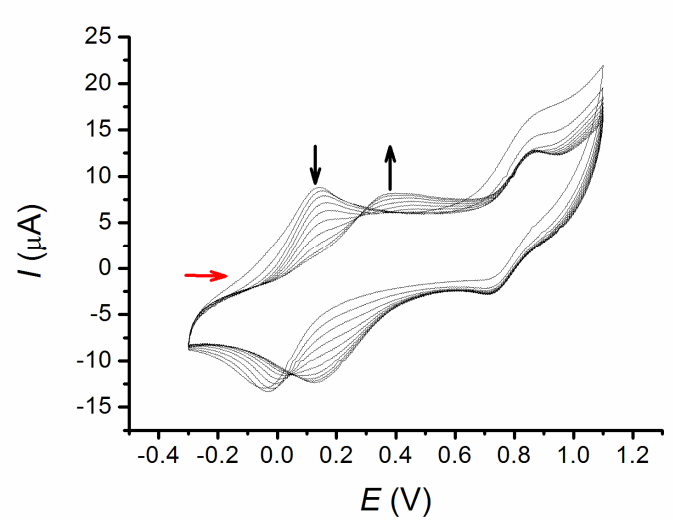

(b)

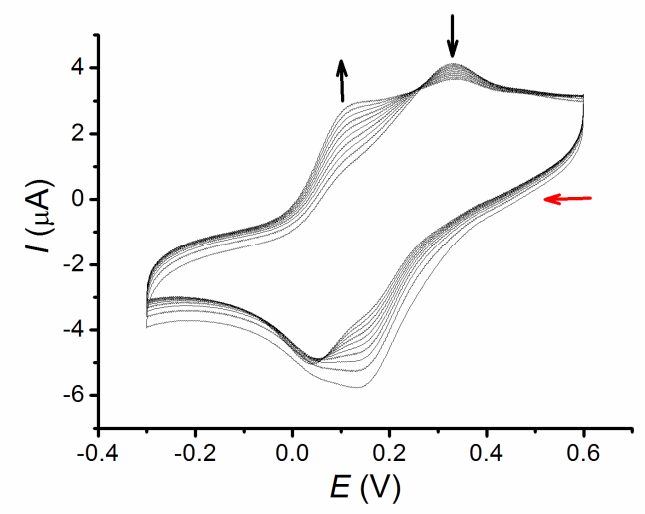

(c)

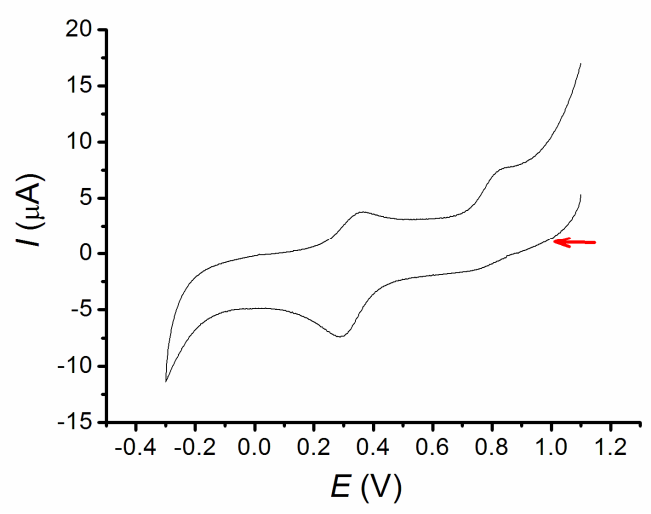

Figure 3. Cyclic voltammograms of complex $\mathbf{1 a}^{+}$in $0.1 \mathrm{M} \mathrm{TBAH}$ in $\mathrm{MeOH}$, at different scan rates and scanning directions (red arrows). The black arrows indicate the intensity increase or decrease: (a) scanning anodically at a scan rate of $400 \mathrm{mV} / \mathrm{s}$ with a previous equilibration time of $20 \mathrm{~min}$ at $-0.30 \mathrm{~V}$. (b) scanning cathodically at a scan rate of $200 \mathrm{mV} / \mathrm{s}$ and with an equilibration time of $45 \mathrm{~min}$ at $0.60 \mathrm{~V}$; (c) $50 \mathrm{mV} / \mathrm{s}$ scanning cathodically after holding the potential at $1.10 \mathrm{~V}$ for 3 minutes.

Figure 3a shows the cyclic voltammograms obtained for $\mathbf{1 a}^{+}$scanning anodically at $400 \mathrm{mV} / \mathrm{s}$. The first scan shows the presence of two quasireversible waves at $E_{1 / 2}=0.07 \mathrm{~V}\left(E_{p, a}=0.12 \mathrm{~V}, E_{p, c}=-0.03 \mathrm{~V}, \Delta E=150 \mathrm{mV}\right)$ and at $E_{1 / 2}=0.78 \mathrm{~V}\left(E_{p, a}=\right.$ $\left.0.84 \mathrm{~V}, E_{p, c}=0.73 \mathrm{~V}, \Delta E=110 \mathrm{mV}\right)$, that are assigned to the following redox couples,

$$
\begin{aligned}
& \mathrm{N}_{5}-\mathrm{Ru}^{\mathrm{II}}--\mathbf{R u}^{\mathrm{III}}-\mathrm{ON}_{4}(\mathrm{Pz})+1 \mathrm{e}-\quad->\quad \mathrm{N}_{5}-\mathrm{Ru}^{\mathrm{II}}--\mathbf{R u}^{\mathrm{II}}-\mathrm{ON}_{4}(\mathrm{Pz}) \quad E_{1 / 2}=0.07 \mathrm{~V} \\
& 1 \mathbf{a}^{+} \\
& 1 \mathrm{a}
\end{aligned}
$$

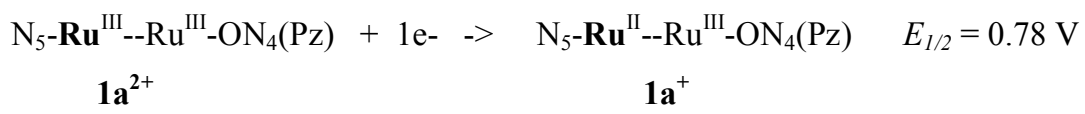

The equation numbering is in accordance with Scheme 3. And the Ru metal undergoing a change in oxidation state is marked in bold. This assignment is based on related mononuclear complexes that contain exactly the same first coordination envi- 
ronment for the $\mathrm{Ru}$ center (Table 1). In addition the one electron nature of the process at $E_{1 / 2}=0.07 \mathrm{~V}$ was corroborated by bulk electrolysis (see Supporting Information Figure S3).

As repetitive cycles are carried out the presence of a new wave at $E_{1 / 2}=0.30 \mathrm{~V}\left(E_{p, a}=0.38 \mathrm{~V}, E_{p, b}=0.17 \mathrm{~V}, \Delta E=210 \mathrm{mV}\right)$ appears, that is associated with the linkage isomerization that occurs when the N-pyrazolyl is replaced by the N-pyridyl group once the $\mathrm{Ru}(\mathrm{III}, \mathrm{III})$ species are reached, that is,

$k_{1}$

$\mathrm{N}_{5}-\mathrm{Ru}^{\mathrm{III}}-\mathrm{Ru}^{\mathrm{III}}-\mathrm{ON}_{4}(\mathrm{Pz}) \quad=>\mathrm{N}_{5}-\mathrm{Ru}^{\mathrm{III}}--\mathrm{Ru}^{\text {III }}-\mathrm{ON}_{4}(\mathrm{Py})$

$1 \mathbf{a}^{2+} \quad \mathbf{1 b}^{3+}$

This newly generate species has one wave at $0.30 \mathrm{~V}$ as indicated previously,

$$
\begin{gathered}
\mathrm{N}_{5}-\mathrm{Ru}^{\mathrm{II}}--\mathbf{R u}^{\mathrm{III}}-\mathrm{ON}_{4}(\mathrm{Py}) \\
\mathbf{1 b}^{\mathbf{2}+}
\end{gathered}
$$

and the second one that appears at the same potential as the parent complex, 
Another interesting feature of this system is observed when a CV of $\mathbf{1 a}^{+}$is performed after holding the potential at $1.10 \mathrm{~V}$ for 3 minutes as shown in Figure 3c. As it can be observed in the cathodic scan the wave at $0.78 \mathrm{~V}$ has completely disappeared and only one wave at $0.30 \mathrm{~V}$ is observed. This is consistent with the generation of species $\mathbf{1} \mathbf{c}^{2+}$, as has been corroborated with a CV prepared from an authentic sample. Thus the wave observed now is due to,

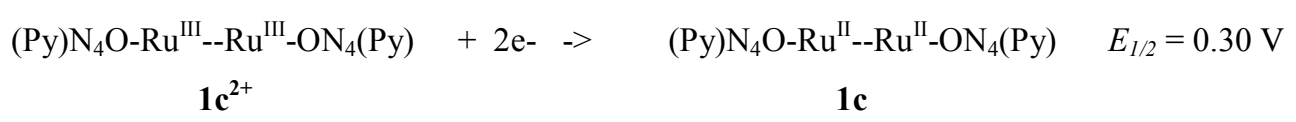

Since the starting material is $\mathbf{1 a}^{+}$, and we have indicated earlier that after one electron removal to form, $\mathbf{1} \mathbf{a}^{2+}$, this species quickly isomerizes to $\mathbf{1 b}^{3+}$, it seem reasonable that $\mathbf{1 b}^{3+}$ in turn also isomerizes to $\mathbf{1} \mathbf{c}^{2+}$ but at a slower rate than the former,

$$
\begin{aligned}
& k_{3} \\
& \mathrm{~N}_{5}-\mathrm{Ru}^{\mathrm{III}}--\mathrm{Ru}^{\mathrm{III}}-\mathrm{ON}_{4}(\mathrm{Py})<=>(\mathrm{Py}) \mathrm{N}_{4} \mathrm{O}-\mathrm{Ru}^{\mathrm{III}}--\mathrm{Ru}^{\mathrm{III}}-\mathrm{ON}_{4}(\mathrm{Py})(8) \\
& \mathbf{1 b}^{3+} \quad \mathbf{1 c}^{2+}
\end{aligned}
$$

\section{Catalytic activity.}

Complex $\mathbf{1 a}^{+}$has been tested with regard to its ability to oxidize cis- $\beta$-methylstyrene, together with related mononuclear complexes of formula $\left[\mathrm{Ru}^{\mathrm{II}} \mathrm{Cl}(\mathrm{Hpbl})(\mathrm{trpy})\right]^{+},{ }^{10}$ and the results are reported in Table 3 . The Table also contains the perfor-

\begin{tabular}{|c|c|c|c|c|c|}
\hline Catalyst & $\begin{array}{l}\text { Conv. } \\
(\%)\end{array}$ & $\begin{array}{l}\text { [Epox], M } \\
\text { Cis/Trans Selec. }{ }^{\mathrm{b}}(\%)\end{array}$ & $\mathrm{TN}^{\mathrm{c}}$ & $\mathrm{TOFi}^{\mathrm{d}}$ & Reference \\
\hline $1 \mathbf{a}^{+}$ & 100 & $0.71(94)$ & 401 & 39 & $\mathrm{tw}^{\mathrm{e}}$ \\
\hline$\left\{[\mathrm{Ru}(\operatorname{trpy})]_{2}\left(\mu-\mathrm{OOCH}_{3}\right)(\mu-\mathrm{bpp})\right\}^{2+}$ & 100 & $0.80(93)$ & 452 & 36 & $8 \mathrm{c} ?$ \\
\hline in $-[\mathrm{RuCl}(\mathrm{Hpbl})(\operatorname{trpy})]^{+}$ & 100 & $0.74(92)$ & 499 & 22 & tw \\
\hline in $-\left[\mathrm{Ru}(\operatorname{trpy})(\mathrm{Hbpp})\left(\mathrm{H}_{2} \mathrm{O}\right)\right]^{+}$ & 100 & $0.81(56)$ & 458 & 20 & tw? \\
\hline$\left\{\left[\mathrm{Ru}(\operatorname{trpy})\left(\mathrm{H}_{2} \mathrm{O}\right)\right]_{2}(\mu-\mathrm{pdz}-\mathrm{dc})\right\}^{2+}$ & 92 & $1.32(100)$ & 1320 & 660 & $8 \mathrm{a}$ \\
\hline$\left\{\left[\mathrm{Ru}^{\mathrm{II}}(\operatorname{trpy})\left(\mathrm{H}_{2} \mathrm{O}\right)\right]_{2}(\mu-\mathrm{pyr}-\mathrm{dc})\right\}^{+}$ & 100 & $0.98(100)$ & 980 & 9180 & $8 \mathrm{c}$ \\
\hline
\end{tabular}

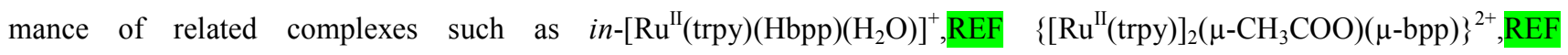
$\left\{\left[\mathrm{Ru}^{\mathrm{II}}(\operatorname{trpy})\left(\mathrm{H}_{2} \mathrm{O}\right)\right]_{2}(\mu-\mathrm{pdz}-\mathrm{dc})\right\}^{2+},{ }^{\mathrm{a} a}$ and $\left\{\left[\mathrm{Ru}^{\mathrm{II}}(\operatorname{trpy})\left(\mathrm{H}_{2} \mathrm{O}\right)\right]_{2}(\mu-\text { pyr-dc })\right\}^{+8 \mathrm{c}}$ for comparison purposes.

Table 3. Catalytic epoxidation of $c i s-\beta$-methylstyrene with $\mathrm{PhIO}$ by means of $\mathbf{1 a}^{+}$and related monoand dinuclear complexes for purposes of comparison. ${ }^{\mathrm{a}}$

\footnotetext{
${ }^{a}$ Reaction conditions, Cat. $1.0 \mathrm{mM}$ for mononuclear and $0.5 \mathrm{mM}$ for dinuclear complexes/alkene $1.0 \mathrm{M} / \mathrm{PhI}(\mathrm{OAc})_{2} 2.0 \mathrm{M} / \mathrm{H}_{2} \mathrm{O}$

2.0. M/biphenyl $0.4 \mathrm{M} / 1,2$-dichloroethane up to a final volume of $1.4 \mathrm{~mL}$.

${ }^{\mathrm{b}} \mathrm{Cis} /$ Trans epoxide selectivity

${ }^{\mathrm{c}} \mathrm{TN}$ is the turnover number with regard to epoxide formation.

${ }^{\mathrm{d}} \mathrm{TOF}_{\mathrm{i}}$ is the initial turnover frequency expressed in epoxide cycles per hour

${ }^{\mathrm{e}}$ this work
}

As general methodology, the catalytic reactions have been carried out using a Cat:Subs:Ox ratio of 1:1000:2000 (mononuclear catalysts) or 1:2000:4000 (dinuclear catalysts) using PhIO as oxidant. The latter as well as the formation of the corresponding $\mathrm{Ru}-\mathrm{OH}_{2}$ and its active higher oxidation state $\mathrm{Ru}=\mathrm{O}$ species, from $\mathrm{Ru}-\mathrm{Cl}$, is favored by allowing to stir at room temperature for 120 minutes, before adding the corresponding substrate. Product distribution of the catalytic reaction was monitored by GC and GC-MS. 
In all cases the catalysts activity observed is very high leading to substrate transformations of $100 \%$. The product distribution observed is basically the epoxide and the products derived from $\mathrm{C}-\mathrm{C}$ bond scission such as benzaldehyde.

Complex $\mathbf{1 a}^{+}$generates a $0.71 \mathrm{M}$ concentration of $c i s$ - $\beta$-methylstyrene oxide after $16 \mathrm{~h}$. Similarly, its mononuclear Ru-Hpbl counterpart, in-[RuCl(Hpbl)(trpy) $]^{+}$, produce a final epoxide concentration of $0.74 \mathrm{M}$ after $20 \mathrm{~h}$.

The catalytic activity observed here for the binuclear $\mathbf{1 a}^{+}$is comparable to that of several mononuclear complexes earlier described in the literature ${ }^{6 a-b, 8 b}$. This is due to the fact that once the high oxidation states are accessed the linkage isomerization isomerization process can occur very fast, generating $\mathbf{1} \mathbf{c}^{2+}$ type of species. This hampers both the electronic communication between the two Ru centres (due to pyrazolyl decoordination) and the potential through-space interaction of the active $\mathrm{Ru}$-oxo groups (see the X-ray structure of $\mathbf{1 c}^{2+}$ ) that would otherwise confer a cooperative effect of the two Ru centers incomplex $1 \mathbf{a}^{+}$.

A second run was carried out isolating the catalyst upon addition of diethylether and repeating the same protocol. The results obtained were basically the same based on stereoselectivity but the TNs were about $10-15 \%$ lower. This decrease is due to partial loss of catalyst during the operations for the recovery process and to a certain extend to potentially deactivation pathways. These results together with the $100 \%$ substrate conversion indicate that the catalyst stability is relatively high.

A very interesting feature of these complexes is their capacity to reach very high cis-/trans-epoxide stereoselectivity giving in all cases more than $90 \%$ of the corresponding cis-epoxide (see Table 3 ).

Finally as can be deduced from Table 3, the velocity at which the epoxidation reaction occurs is directly related to the multianionic nature of the backbone dinucleating ligand. In this respect the complex containing the $\mu-p y r-\mathrm{dc}^{3-}$ ligand has by far the largest TOF.

\section{Conclusions}

Three dinuclear $\mathrm{Ru}-\mathrm{Cl}$ complexes containing the $\mathrm{Hpbl}$ and trpy ligands, $\left\{[\mathrm{RuCl}(\operatorname{trpy})]_{2}\left(\mu-\mathrm{pbl}-\kappa-\mathrm{N}^{3} \mathrm{O}\right)\right\}^{+}\left(\mathbf{1} \mathbf{a}^{+}\right)$, $\left\{[\operatorname{RuCl}(\operatorname{trpy})]_{2}\left(\mu-\mathrm{Hpbl}-\kappa-\mathrm{N}^{3} \mathrm{O}\right)\right\}^{2+}\left(\mathbf{1} \mathbf{b}^{2+}\right)$, and $\left\{[\mathrm{RuCl}(\operatorname{trpy})]_{2}\left(\mu-\mathrm{Hpbl}-\kappa-\mathrm{N}^{2} \mathrm{O}^{2}\right)\right\}^{2+}\left(\mathbf{1} \mathbf{c}^{2+}\right)$ have been prepared, isolated and characterized by analytic and spectroscopic techniques. The coordination versatility of the Hpbl ligand allows the presence of multiple isomers that can be obtained depending on the Ru oxidation state and confers the system and extremely rich chemistry with regard to the potential isomers that can be obtained. In particular fast $\mathrm{N}(\mathrm{Pz})->\mathrm{N}(\mathrm{Py})\left(\mathrm{Hpbl}\right.$ acting from $\left.\kappa-\mathrm{N}^{3} \mathrm{O}\right)$ linkage isomerization is observed for the Hpbl ligand for $\mathbf{1} \mathbf{a}^{2+}$ upon reaching oxidation state III,III. In sharp contrast the opposite reaction occurs when oxidation state II,II is obtained. Finally, $\mathbf{1 a}^{+}$and its recently reported mononuclear analogue, in$[\mathrm{RuCl}(\mathrm{Hpbl})(\mathrm{trpy})]^{+}$, have been tested as catalysts for the epoxidation of $c i s$ - $\beta$-methylstyrene

\section{ASSOCIATED CONTENT}

Supporting Information. Further spectroscopic (1D and 2D NMR) and spectroelectrochemical measurements for the reported complexes. This material is available free of charge via the Internet at http://pubs.acs.org."

\section{AUTHOR INFORMATION}

\section{Corresponding Author}


*E-mail: 1luis.escriche@uab.cat (L.E.), allobet@iciq.es (A.L.), xavier.sala@uab.cat (X.S.)

\section{ACKNOWLEDGMENT}

Support from MINECO (CTQ-2013-49075-R, CTQ2011-26440, and CTQ2011-23156-C02-02) is gratefully acknowledged. L.F. and R.M. G.-G. are grateful for the award of the FI-UAB and PIF doctoral grants from UAB, respectively.

\section{REFERENCES}

[1] Hauser, S. A.; Cokoja, M.; Kühn, F. E. Catal. Sci. Technol. 2013, 3, 552-561.

[2] Cavani, F.; Teles, J. H. ChemSusChem, 2009, 2, 508.

[3] Roberts, S.M.; Whittall, J. Eds., Catalysts for fine chemical synthesis: Regio- and stereo-controlled oxidations and reductions, Vol. 5; John Wiley Sons, Ltd: England, 2007.

[4] (a) Sala, X.; Escriche, L.; Llobet, A. in Molecular Solar Fuels, 1st ed., Chapter 10 (Eds.: T. J. Wydrzynski and W. Hillier), Royal Society of Chemistry, 2012, pp. 273-288. (b) Berardi, S.; Drouet, S.; Francas, L.; Gimbert-Surinach, C.; Guttentag, M.; Richmond, C.; Stoll, T.; Llobet, A. Chem. Soc. Rev. 2014, DOI: 10.1039/C3CS60405E.

[5] (a) Meyer, T. J.; Huynh, M. H. V. Inorg. Chem. 2003, 42, 8140-8160. (b) Dovletoglou, A.; Adeyemi, S. A.; Meyer, T. J. Inorg. Chem. 1996, 35, 4120-4127. (c) Suen, H. F.; Wilson, S. W.; Pomerantz, M.; Walsh, J. L. Inorg. Chem. 1989, 28, 786791. (d) Roecker, L.; Kutner, W.; Gilbert, J. A.; Simmons, M.; Murray, R. W.; Meyer, T. J. Inorg. Chem. 1985, 24, 37843791. (e) Takeuchi, K. J.; Thompson, M. S.; Pipes, D. W.; Meyer, T. J. Inorg. Chem. 1984, 23, 1845-1851. (f) Binstead, R. A.; Moyer, B. A.; Samuels, G. J.; Meyer, T. J. J. Am. Chem. Soc. 1981, 103, 2897-2899. (g) Moyer, B. A.; Meyer, T. J. Inorg. Chem. 1981, 20, 436-444. (h) Moyer, B. A.; Meyer, T. J. J. Am. Chem. Soc. 1978, 100, 3601-3603.

[6] (a) Sala, X.; Santana, N.; Serrano, I.; Plantalech, E.; Romero, I.; Rodríguez, M.; Llobet, A.; Jansat, S.; Gómez, M.; Fontrodona, X. Eur. J. Inorg. Chem. 2007, 5207-5214. (b) Serrano, I.; Sala, X.; Plantalech, E.; Rodríguez, M.; Romero, I.; Jansat, S.; Gómez, M.; Parella, T.; Stoeckli-Evans, H.; Solans, X.; Font-Bardia, M.; Vidjayacoumar, B.; Llobet, A. Inorg. Chem. 2007, 46, 5381-5389. (c) Sala, X.; Poater, A.; Romero, I.; Rodríguez, M.; Llobet, A.; Solans, X.; Parella, T.; Santos, T. M. Eur. J. Inorg. Chem. 2004, 612-618. 
[7] (a) Planas, N.; Christian, G. J.; Mas-Marza, E.; Sala, X.; Fontrodona, X.; Maseras, F.; Llobet, A. Chem. Eur. J. 2010, 16, 7965-7968. (b) Aguiló, J.; Naeimi, A.; Bofill, R.; Mueller-Bunz, H.; Llobet, A.; Escriche, L.; Sala, X.; Albrecht, M. New J. Chem. 2014, 38, 1980-1987.

[8] (a) Di Giovanni, C.; Vaquer, L.; Sala, X.; Benet-Buchholz, J.; Llobet A. Inorg. Chem. 2013, 52, 4335-4345. (b) GarcíaAntón, J.; Bofill, R.; Escriche, L.; Llobet, A.; Sala, X. Eur. J. Inorg. Chem. 2012, 4775-4789 and references therein. (c) Di Giovanni, C.; Poater, A.; Benet-Buchholz, J.; Cavallo, L.; Solà, M.; Llobet, A. Chem. Eur. J, 2014, 20, 3898-3902

[9] (a) Francàs, L.; Sala, X.; Escudero-Adán, E.; Benet-Buchholz, J.; Escriche, L.; Llobet, A. Inorg. Chem. 2011, 50, 27712781. (b) Francàs, L.; Sala, X.; Benet-Buchholz, J.; Escriche, L.; Llobet, A. ChemSusChem 2009, 2, 321-329. (c) Lopez, I.; Ertem, M. Z.; Maji, S.; Benet-Buchholz, J.; Keidel, A.; Kuhlmann, U.; Hildebrandt, P.; Cramer, C. J.; Batista, V. S.; Llobet, A. Angew. Chem. Inter. Ed. 2014, 53, 205-209.

[10] Francàs, L.; González-Gil, R. M.; Poater, A.; Fontrodona, X.; García-Antón, J.; Sala, X.; Escriche, L.; Llobet, A. Inorg. Chem. 2014, 53, 8025-8035.

[11] Sullivan, B.P.; Calvert, J.M.; Meyer, T. J. Inorg. Chem. 1980, 19, 1404.

[12] Data collection with APEX II version v2013.4-1. Bruker (2007). Bruker AXS Inc., Madison, Wisconsin, USA.

[13] Bruker SAINT version V8.30c. Bruker (2007). Bruker AXS Inc., Madison, Wisconsin, USA.

[14] Blessing, Acta Cryst. 1995 A51 33-38. SADABS: V2012/1 Bruker (2001). Bruker AXS Inc., Madison, Wisconsin, USA.

[15] Sheldrick, G.M. Acta Cryst. 2008 A64, 112-122. SHELXTL versions V6.12 and 6.14.

[16] (a) Roeser, S.; Ertem, M. Z.; Cady, C.; Lomoth, R.; Benet-Buchholz, J.; Hammarström, L.; Sarkar, B.; Kaim, W.; Cramer, C. J.; Llobet, A. Inorg. Chem. 2011, 51, 320-327. (b) Sens, C.; Romero, I.; Rodríguez, M.; Llobet, A.; Parella, T.; Benet-Buchholz, J. J. Am. Chem. Soc. 2004, 126, 7798-7799. (c) Sens, C.; Rodríguez, M.; Romero, I.; Llobet, A.; Parella, T.; Benet-Buchholz, J.; Inorg. Chem. 2003, 42, 8385-8394. 
[17] (a) Porterfield, W. W. Inorganic Chemistry: A Unified Approach; Academic Press, Inc. 2nd ed.: San Diego, 1993. (b) Mackay, K. M.; Mackay, R. A. Introduction to Modern Inorganic Chemistry; Blackie Academic \& Professional, 4th ed.: Glasgow, U.K., 1989.

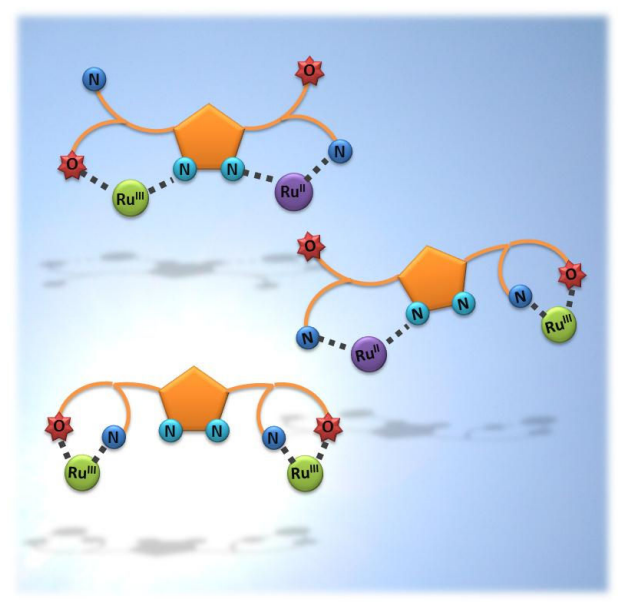

New dinuclear ruthenium complexes with the hemilabile ligand Hpbl have been prepared and characterized. A number of linkage isomerization processes have been studied and monitored by cyclic voltammetry and their catalytic properties with regard to the epoxidation of cis- $\beta$-methylstyrene have been evaluated and compared with related mono- and dinuclear Ruaqua type of complexes. 